\title{
In vivo analgesic activity and safety assessment of Vitis vinifera $L$ and Punica granatum $L$ fruits extracts
}

\author{
Nadia Zeghad ${ }^{1,2 *}$, Aicha Madi ${ }^{1}$, Sihem Helmi ${ }^{1}$ and Abdelmalik Belkhiri ${ }^{1,3}$ \\ ${ }_{1}^{1}$ Laboratoire de Pharmacologie et de Toxicologie, ${ }^{2}$ Faculté des Sciences de la Nature et de la Vie, Université des frères \\ Mentouri Constantine 1, ${ }^{3}$ Laboratoire de Pharmacognosie, Faculté de médecine, Université des frères Mentouri Constantine 3, \\ Algérie
}

${ }^{*}$ For correspondence: Email: zeghadnadia@umc.edu.dz

\begin{abstract}
Purpose: To investigate the analgesic properties of fruit extracts of Vitis vinifera (grape) and Punica granatum (pomegranate) in Albino mal mice.

Methods: The analgesic activity of fruit extracts of $V$. vinifera and $P$. granatum were examined in vivo using thermal stimulus assays (i.e., tail immersion and hot plate) and acetic acid-induced writhing test using acetylsalicylic acid (0.1 g/kg, per os) as standard. The extracts were administered orally in doses of $1.0,2.0$ and $3.0 \mathrm{~g} / \mathrm{kg}$.

Results: In acetic acid writhes test, both fruit extract pretreatments (1.0, 2.0 and $3.0 \mathrm{~g} / \mathrm{kg}$, per os) significantly decreased the number of writhes $(p<0.0001)$ in a dose-dependent manner compared to control. The Index of Pain Inhibition (IPI) values following V. vinifera extract treatments were $36.52 \%$ $(1.0 \mathrm{~g} / \mathrm{kg}), 66.67 \%(2.0 \mathrm{~g} / \mathrm{kg})$ and $89.71 \%(3.0 \mathrm{~g} / \mathrm{kg})$ which were significantly different from those for $P$. granatum extracts (45.39\%, $1.0 \mathrm{~g} / \mathrm{kg}), 70.93 \%, 2.0 \mathrm{~g} / \mathrm{kg}$ ) and $86.88 \%, 3.0 \mathrm{~g} / \mathrm{kg}$ ) at equivalent doses of 2.0 and $3.0 \mathrm{~g} / \mathrm{kg}$ of the extracts The fruit extracts of both species increased the reaction latency time. In tail-immersion assay, only the fruit extract of $P$. granatum significantly increased the response to heat stimulus at doses of $2.0 \mathrm{~g} / \mathrm{kg}(\mathrm{p}<0.05)$.

Conclusion: The hydroalcohol fruit extracts of $P$. granatum and $V$. vinifera have potential analgesic effects. Further studies are needed to determine the active component responsible for this effect.
\end{abstract}

Keywords: Vitis vinifera, Punica granatum, Analgesic activity, Tail immersion test, Hot plate test, mouse writhings inhibition assay

Tropical Journal of Pharmaceutical Research is indexed by Science Citation Index (SciSearch), Scopus, International Pharmaceutical Abstract, Chemical Abstracts, Embase, Index Copernicus, EBSCO, African Index Medicus, JournalSeek, Journal Citation Reports/Science Edition, Directory of Open Access Journals (DOAJ), African Journal Online, Bioline International, Open-J-Gate and Pharmacy Abstracts

\section{INTRODUCTION}

Most drugs currently used for the management of pain and inflammatory conditions are either NSAIDs or opiates [1]. Most of these medicines can carry a risk of adverse side effects (like gastric lesions caused by NSAIDs and tolerance and dependence induced by opiates). They also do not produce effective pain relief in all the cases [2]. According to World Health Organization, traditional herbal remedies are still extensively used by population, particularly throughout all over the rural regions with restricted access to modern medicines [3]. Investigation of pain retrieve potential of plantbased remedies used in the traditional medicine is a viable option to discover new analgesic agents which could be beneficial in the management scheme of pain [4].

An ethno-pharmacological survey of plant-based remedies commonly used to relieve pain, conducted as part of our research program on traditional medicinal plants of the Maghreb 
region, has allowed establishing a priority list of a dozen of plants, among which figure prominently two well-known species, Vitis vinifera (grape) and Punica granatum, (pomegranate). These plants are extensively cultivated from ancient time from Tunisia to Morocco for their socio-economical values. Both species are source of juicy and sweet fruits. Traditional therapeutic uses of both species are well documented in the literature of North Africa traditional medicine through several comprehensive reviews [5-8].

V. vinifera L. (Vitaceae), known locally as "Dalya", is a climbing shrub native to the Mediterranean region, central Europe and southwestern Asia [9]. Leaves, grapes and seeds are described for their astringent, homeostatic and anti-inflammatory properties $[9,10]$. Plant parts are traditionally utilized to stop bleeding, inflammation, and also remedies for painful conditions, such as the kind brought on by hemorrhoids and headaches [7]. Flavonoids (including kampferol-3-0-glucosides, quercetin-3O-glucosides), tannins (procyanidolic oligomers), Stilbenes (resveratrol and viniferins), phenolic acids (tartaric acid, malic acid, succinic acid, citric acid, oxalic acid) and phenylacrylic acid derivatives ( $p$-coumaroyl acid, caffeoyl acid, feruloylsuccinic acid) have been identified in the leaves and fruits of $V$. vinifera [11,12]. From a pharmacological point of view, in vitro and in vivo studies have reported a wide range of biological effects, including anti-inflammatory, antioedematous effect, hepatoprotective activity, antimicrobial activity, antioxidative activity, vasorelaxant effect, spasmolytic effects [13]. The most recent review of the literature conducted on $V$. vinifera revealed no study on the analgesic activity of the edible part of the plant's fruit orbits extracts.

P. granatum L. (Lythraceae), locally called "Rouman", is a fruit-bearing shrub native to the Middle East and now widely cultivated in warm regions of the world, particularly throughout the Mediterranean region [14-17]. The entire fruit is used in folklore medicine as remedy of various diseases, such as dyspepsia, ulcer, hepatic damage, to treat jaundice and diarrhea, and to relieve pain due to sore throat and menstruation in women $[7,18]$. $P$. granatum is characterized by the presence of polyphenols, including ellagic acid, punicic acid, ellagitannin, punicalagin, anthocyanidins, oestrogenic flavonols and flavones [19,20]. Pharmacology studies proved its antimicrobial, antioxidant, anti-inflammatory, anthelminthic and molluscicidal activities [18,19]. Its other benefits include the chemopreventive potential in case of prostate cancer [21].
The current study aims to investigate the possible protective role of alcoholic fruits extracts of $V$. vinifera and $P$. granatum against thermal and chemically induced pain.

\section{EXPERIMENTAL}

\section{Drugs and chemicals}

Acetic acid, acetylsalicylic acid and other chemicals used for extraction purpose and phytochemical screening were purchased from Sigma Aldrich (Poole, UK).

\section{Plant materials}

Mature fresh fruits of the black grape (Vitis vinifera L.) and the pomegranate (Punica granatum $\mathrm{L}$ ), purchased from local markets from the 2012 harvest season, were authenticated by qualified taxonomist. Voucher specimen was stored in the herbarium as appropriate. The fruits were collected in bulk, and washed under running tap water to remove adhering material and the edible portion of each was freeze-dried, powdered using a dry grinder and stored at low temperature $\left(-25^{\circ} \mathrm{C}\right)$ until extracted.

The extraction process was carried out according to Babero et al and Ma et al [22,23]. Samples (25g) were extracted by maceration for $24 \mathrm{~h}$ using $500 \mathrm{ml}$ of methanol/water (70:30) with an automatic shaker, assisted by ultrasound for 30 min at room temperature, and the remaining material was extracted twice under identical conditions. The extracts were combined and filtered; the combined filtrates were concentrated in a rotary evaporator under vacuum at low temperature $\left(<40{ }^{\circ} \mathrm{C}\right)$ to yield the crude extracts which were subjected immediately to lyophilization. Freeze dried samples were kept at low temperature $\left(-25^{\circ} \mathrm{C}\right)$ until required for further experiments. Extracts of both species were reconstituted in distilled water for the evaluation of analgesic activity.

Presence of flavonoids, tannins, alkaloids, saponins, steroids, terpenoids, and coumarins in the extracts was determined as previously described $[24,25]$ :.

\section{Animals}

Adult albino male mice, weighing between 20 $32 \mathrm{~g}$ and aged 4 - 5 weeks, were used for the studies. The animals were kept in standard polypropylene cages at room temperature $(24 \pm$ $2{ }^{\circ} \mathrm{C}$ ) in a $12 \mathrm{~h}$ light/dark cycle. They were allowed free access to standard pellet diet and water ad libitum, and acclimatize to the laboratory conditions for seven days before the 
experiment. The study was carried out following the guidelines of the principles of Laboratory Animal Care "Guide for the Care and Use of Laboratory Animals" [26].

\section{Acute toxicity study}

After an overnight fast, healthy animals were weighed and randomly distributed into 5 groups of six animals each (one control group and four treated groups). The control and herbal groups received per os distilled water and serial doses $(0.5,2.5,5.0$ and $10.0 \mathrm{~g} / \mathrm{kg})$ of extracts reconstituted in distilled water respectively. Each animal was fed by oral gavage using a specially designed mice needle. Animal observation was carried within the first $30 \mathrm{~min}$, then periodically during the first $24 \mathrm{~h}$ and once daily for two weeks. Death or changes in general behavior and other physiological activities of each animal were noted $[27,28]$. Mice of all groups were weighted on days 7 and 14. At the end of the experiment, the animals were sacrificed and their internal organs including heart, liver, kidneys, lungs, and spleen were examined [29,30].

\section{Analgesic activity}

The peripheral analgesic effect of the extracts was evaluated by chemical-induced writhing test [32-34], while the involvement of central mechanisms was studied using the hot-plate and tail-immersion tests as previously reported [31]. These latter assays are known to activate supra spinal and spinal nociceptive pathways, respectively [35]. Tests were conducted after 24 $\mathrm{h}$ fast and healthy animals were then weighed and randomly assigned into groups of six animals each $(n=6)$.

\section{Acetic acid-induced writhing test}

The method described by Collier et al [36], was used. Writhing was elicited by an intraperitoneal (i.p) injection of $1 \%$ acetic acid aqueous solution. Animals were pretreated with fruits extracts $(1.0,2.0$ and $3.0 \mathrm{~g} / \mathrm{kg}$ per os, single dose) reconstituted in distilled water, and acetylsalicylic acid (standard drug, $0.1 \mathrm{~g} / \mathrm{kg}$, per os). Then they were allowed to adapt for $60 \mathrm{~min}$ before intraperitoneal (i.p) injection of acetic acid aqueous solution. The number of writhes in 20 min was recorded for each mouse.

Index of Pain Inhibition (IPI) was expressed as in Eq 1.

$\mathrm{IPI}=[(\mathrm{Nc}-\mathrm{Nt}) /(\mathrm{Nc})] \times 100$ where Nc represents the number of writhes observed for control group, and $\mathrm{Nt}$ :is number of writhes in tested groups (fruit extracts or acetylsalicylic acid).

\section{Central nervous system analgesic activity}

Central analgesic activity was monitored using both the hot plate and tail immersion tests.

Hot plate test: Hot plate test was performed according to the method previously described [33]. Five groups of mice (6 mice per group) each received, $1 \mathrm{~h}$ before testing, fruit extracts at different doses $(1.0,2.0$ and $3.0 \mathrm{~g} / \mathrm{kg}$, single dose, per os), distilled water (control), and acetylsalicylic acid $(0.1 \mathrm{~g} / \mathrm{kg}$, per os). The animals were placed on a heated surface of a hot plate maintained at $55.0 \pm 0.5^{\circ} \mathrm{C}$. The pain threshold was considered to be reached when the animals licked their hind paws or jumped out [37].

Tail immersion test: Tail immersion test was performed using an adapted method described previously [34]. Each of five groups of mice (6 mice per group) received different doses (1.0, 2.0 and $3.0 \mathrm{~g} / \mathrm{kg}$, single dose, per os) of the extract, distilled water (control), and acetylsalicylic acid $(0.1 \mathrm{~g} / \mathrm{kg}$, per os). The lower portion of each animal tail was immersed gently in a hot water bath maintained at $55.0 \pm 0.5{ }^{\circ} \mathrm{C}$ for some seconds and withdrawn as soon as the mice reacted. The time it took each animal to withdraw its tail was recorded (using a chronometer) [38].

\section{Statistical analysis}

The results of pharmacological testing were expressed as mean \pm SD and analyzed using Tukey test (HSD) to determine the level of significance. A 2-tailed $p$ value less than 0.05 was considered to be significant.

\section{RESULTS}

\section{Acute toxicity}

Fruit extracts did not produce mortality of any animal within $24 \mathrm{~h}$ at the concentrations used. Moreover, there was no visible signs of acute toxicity up to $10.0 \mathrm{~g} / \mathrm{kg}$ within 14 days of observation. Macroscopic examination performed later on the main organs (heart, liver, kidneys, lungs, spleen) also revealed no abnormality.

\section{Analgesic activity}

Results of acetic acid induced abdominal writhing test are provided in Table 1. 
Table 1: Anti-nociceptive effect of fruits extracts and acetylsalicylic acid on acetic acid-induced pain in mice

\begin{tabular}{|c|c|c|}
\hline Drug/Plant extract & Dose $(\mathrm{g} / \mathrm{kg})$ & $\begin{array}{c}\text { Number of writhings* } \\
\text { (IPI, \%) }\end{array}$ \\
\hline Control (distilled water) & - & $94.00 \pm 3.03(-)$ \\
\hline Acetylsalicylic acid & 0.1 & $22.50 \pm 1.00 \#(76.06 \%)$ \\
\hline \multirow[t]{3}{*}{ Vitis vinifera } & 1.0 & $59.67 \pm 4.76^{\# \square}(36.52 \%)$ \\
\hline & 2.0 & $31.33 \pm 5.95^{\#-(66.67 \%)}$ \\
\hline & 3.0 & $09.67 \pm 1.97^{\# \square}(89.71 \%)$ \\
\hline \multirow[t]{3}{*}{ Punica granatum } & 1.0 & $51.33 \pm 0.82^{\# \varpi}(45.39 \%)$ \\
\hline & 2.0 & $27.33 \pm 5.43^{\#}(70.93 \%)$ \\
\hline & 3.0 & $12.33 \pm 4.41^{\# !}(86.88 \%)$ \\
\hline
\end{tabular}

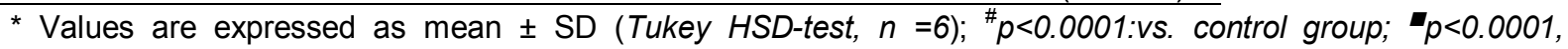

${ }^{\square} p 0.01$ vs. acetylsalicylic acid (standard drug)treated group; IPI: Index of Pain Inhibition (\%)

Table 2: Central analgesic activities of the fruit extracts, measured by hot plate and tail immersion tests

\begin{tabular}{|c|c|c|c|}
\hline \multirow{2}{*}{ Drug/Plant extract } & \multirow{2}{*}{$\begin{array}{l}\text { Dose } \\
\text { (g/kg) }\end{array}$} & \multicolumn{2}{|c|}{ Reaction time (s) * } \\
\hline & & Hot plate test & Tail immersion test \\
\hline Control & - & $02.98 \pm 0.47$ & $02.12 \pm 0.51$ \\
\hline Acetylsalicylic acid & 0.1 & $01.92 \pm 0.61^{\Delta \Delta}$ & $02.80 \pm 1.17$ \\
\hline \multirow{3}{*}{ Vitis vinifera } & 1.0 & $03.16 \pm 0.82$ & $02.38 \pm 0.61$ \\
\hline & 2.0 & $04.17 \pm 1.09$ & $02.43 \pm 0.60$ \\
\hline & 3.0 & 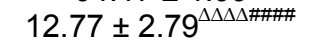 & $03.06 \pm 1.32$ \\
\hline \multirow[t]{3}{*}{ Punica granatum } & 1.0 & $04.13 \pm 0.6$ & $02.39 \pm 0.49$ \\
\hline & 2.0 & 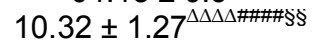 & $03.31 \pm 0.96^{\Delta}$ \\
\hline & 3.0 & 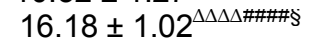 & $03.90 \pm 0.51^{\Delta \Delta \Delta}$ \\
\hline
\end{tabular}

${ }^{*} \mathrm{RT}$ in seconds expressed as mean $\pm \mathrm{SD}$, Tukey (HSD)-test, $\mathrm{n}=6 ;{ }^{\Delta} p<0.05,{ }^{\Delta \Delta} p<0.01,{ }^{\Delta \Delta \Delta} p<0.001,{ }^{\Delta \Delta \Delta \Delta} p$ <0.0001: compared to control group; ${ }^{\#} p<0.05,{ }^{\#} p<0.01,{ }^{\# \#} p<0.001,{ }^{\# \# \#} p<0.0001$ : compared to acetylsalicylic acid treated group. ${ }^{\S} \mathrm{P}<0.01,{ }^{\S \S} \mathrm{P}<0.0001$ : compared to $V$. vinifera treated group

Treatment with each of the fruit extracts $(1.0,2.0$ and $3.0 \mathrm{~g} / \mathrm{kg}$, per os) significantly $(p<0.0001)$ reduced, in a dose-dependent manner, the number of writhes induced by acetic acid when compared to control (Table 1). V. vinifera extract treatments produced IPI values of $36.52 \%(1.0$ $\mathrm{g} / \mathrm{kg}), 66.67 \%(2.0 \mathrm{~g} / \mathrm{kg})$ and $89.71 \%(3.0 \mathrm{~g} / \mathrm{kg})$. However, the corresponding values of IPI for $P$. granatum extract treatments were $45.39 \%$ (1.0 $\mathrm{g} / \mathrm{kg}), 70.93 \%(2.0 \mathrm{~g} / \mathrm{kg})$ and $86.88 \%(3.0 \mathrm{~g} / \mathrm{kg})$. At each of the extract doses of 2.0 and $3.0 \mathrm{~g} / \mathrm{kg}$, the withes were not significantly different for the extracts of the different species. It is noteworthy that fruit extracts administered at a dose of 3.0 $\mathrm{g} / \mathrm{kg}$, the extracts produced writhing inhibition effect significantly $(p<0.0001)$ significantly different from that observed in the acetylsalicylic acid $(0.1 \mathrm{~g} / \mathrm{kg})$ pre-treated group (Table 1$)$.

The tail immersion assay revealed no significant difference in reaction time observed between the control group and $V$. vinifera pretreated groups over the range of tested doses (1.0, 2.0 and 3.0 $\mathrm{g} / \mathrm{kg}$ ), or between the different fruit extracts (Table 2). Similarly, no significant difference was noted between the acetylsalicylic acid group and control group. However, mice groups receiving doses of 2.0 and $3.0 \mathrm{~g} / \mathrm{kg}$ of $P$. granatum extract showed a significant increase in reaction time in comparison to the control group. These values of reaction time measured for $P$. granatum extract groups at doses of $(2.0,3.0 \mathrm{~g} / \mathrm{kg})$ were even superior to those for the acetylsalicylic acid group.

In the hot plate assay, both groups of mice treated with $V$. vinifera extract (at doses of 3.0 $\mathrm{g} / \mathrm{kg}$ ) and $P$. granatum extract (at doses of 2.0 and $3.0 \mathrm{~g} / \mathrm{kg}$ ) showed significant increase in reaction time when compared with the control group. Compared to $V$. vinifera treatment, $P$. granatum extract was significantly more potent when administrated at the same doses $(1.0,2.0$ and $3.0 \mathrm{~g} / \mathrm{kg}$ ). At all treated doses $(1.0,2.0$ and $3.0 \mathrm{~g} / \mathrm{kg}$ ), fruit extract protection against pain was dose-dependent and significantly greater than that obtained for acetylsalicylic acid at a dose of $0.1 \mathrm{~g} / \mathrm{kg}$.

\section{DISCUSSION}

To investigate the analgesic potential of fruit extracts of Punica granatum and Vitis vinifera, three different experiments were conducted. The peripheral analgesic effect of the extracts was tested by using the chemical (acetic acid) induced writhing test which is widely accepted as a model for visceral pain $[39,40]$. The involvement of central mechanisms was studied by using the hot-plate and tail-immersion tests, 
known to activate supra-spinal nociceptive and spinal nociceptive pathways, respectively $[39,40]$. In toxicity studies, substances that presents $\mathrm{LD}_{50}$ higher than $5.0 \mathrm{~g} / \mathrm{kg}$ administered by oral route is considered practically non-toxic [41].

Although no significant difference was seen between the alcoholic fruit extracts of $P$. granatum and $V$. vinifera at doses of $2.0 \mathrm{~g} / \mathrm{kg}$ and $3.0 \mathrm{~g} / \mathrm{kg}$ in acetic acid writhing test, these species produced a significant $(p<0.0001)$ dose-related peripheral analgesic effect $(1.0,2.0$ and $3.0 \mathrm{~g} / \mathrm{kg}$ ) compared to control. These results are in agreement with previous reports on antinociceptive effect using the entire fruit, peel or seed extracts of the plants $[45,46]$.

Furthermore, it is established that the abdominal constriction response is induced by activation of local peritoneal receptors by mediators of pain [42]. Thus, the peripheral analgesic effect of the fruit extracts could be mediated by inhibition of the release of these endogenous nociceptive mediators [43].

The results from the hot-plate test and tailimmersion assay clearly show that the fruit extract of $P$. granatum possesses analgesic potential which suggests the existence of both peripherally and centrally mediated mechanisms as demonstrated by acetic acid writhing, tail immersion and hot plate assays. This assumption is in agreement with previous reports on extracts from different parts of $P$. granatum $[47,55]$. Similarly, results obtained for $V$. vinifera, in the different experiments favors analgesic effect due to peripheral and central-based mechanisms. This is thought to involve only supraspinal nociceptive pathway as earlier reported $[46,49,56]$.

The chemistry of these plants (pomegranate and grape) is characterized by the presence of high amount of phenolic compounds, including tannins and flavonoïds. These constituents are known to possess analgesic and antiinflammatory effects in experimental animals $[47,48,51,54,56,57]$.

\section{CONCLUSION}

This study demonstrates that the fruits extracts of $V$. vinifera and $P$. granatum exhibit significant analgesic activities using acetic acid induced writhing, hot-plate and tail-immersion assays. These plants are thus good candidates for development of herbal-based drugs as alternatives for management of pain and inflammatory conditions.

\section{DECLARATIONS}

\section{Acknowledgement}

Authors are thankful to the laboratory of Botany and Pharmacognosy, Medical Faculty, Constantine University 3, for their help, in identification and authentication of the plants.

\section{Conflict of Interest}

No conflict of interest associated with this work.

\section{Contribution of Authors}

The authors declare that this work was done by the authors named in this article and all liabilities pertaining to claims relating to the content of this article will be borne by them.

\section{REFERENCES}

1. Rang HP, Urban L. New molecules in analgesia. Brit $J$ Anaesth. 1995; 75: 145-156.

2. Sostres C, Gargallo CJ, Lanas A. Nonsteroidal antiinflammatory drugs and upper lower gastrointestinal mucosal damage. Arthrit Res \& Therapie. 2013; 15(3): 1-8.

3. Ammara H, Rahman S, Deeba F, Shahid M. Antimicrobial activity of some plant extracts having hepatoprotective effects. J. Med. Plants Res. 2009; 3(1): 20-23.

4. Salim AA. Chin $Y W$, Kinghorn AD. Drug Discovery from Plants (in Bioactive Molecules and Medicinal Plants, eds. Ramawat K.G. Mérillon J-M.).Berlin: SpringerVerlag, Heidelbe; 2008; 1-18p.

5. Boulos L. Medicinal plants of North Africa. References Publications, Inc Michigan.1983.

6. Muhammad Ibn Hamadush A. Révélation des énigmes dans l'exposition des drogues et des plantes, (Traduction de Leclerc L.). Beirut: Dar al-Kotob alIlmiya. 1996.

7. Baba Aissa F. Encyclopédie des plantes utiles. Edition El-Maarifa. 2011.

8. Bellakhdar J. La pharmacopée marocaine traditionnelle, médecine arabe ancienne et savoirs populaires. Paris: Ibis Press Editions. 1997; 320-321.

9. Min H, Henglu T, Xiaowen L, Xiaohua Q, Xuehao C. Molecular progress in research on fruit astringency. Molecules. 2015; 20: 143-151.

10. El Hawary S, El Fouly K, El Gohary HM, Meselhy KM, Salem A, Talaat Z. Phytochemical and biological investigation of Vitis vinifera L. (Flame cultivars), Vitaceae cultivated in Egypt. Nat sci. 2012; 10(10): 4859.

11. Ruaa AJ, Denisa M, Dogaru E. Study regarding the influence of Vitis vinifera fruit (Muscat of Hamburg species) on some biochemical parameters. Farmacia. 2010; 58(3): 332-340.

Trop J Pharm Res, September 2016; 15(9): 1919 
12. Monica M. Vitis vinifera (Grape) ingredients as used in cosmetics, Scientific Literature Review. 2012; 1-29p.

13. European Medicines Agency. Assessment report on Vitis vinifera L., folium. Committee on herbal medicinal products (HMPC).[cited 2010]. Available from : (www.ema.europa.eu)

14. Saad H, Charrier El Bouhtoury F, Pizzi A, Rode K, Charrier B, Ayed N. Characterization of pomegranate peels tannins extractives. Ind crop prod. 2012; 40: 239 246.

15. Raafat K, Samy W. Amelioration of diabetes and painful diabetic neuropathy by Punica granatum $L$ extract and its spray dried biopolymeric dispersions, Hindawi publishing corporation; Evidence-based complementary and alternative medicine. 2014; 1-12p.

16. Debjit B, Harish G, Pragati Kumar B, Duraivel S, Aravind $G$, Sampath Kumar KP. Medicinal uses of Punica granatum and its health benefits. J Pharmacogn\&Phytochem. 2013; 1(5): 28-35.

17. Bellakhdar J. Le Maghreb à travers ses plantes. Barzakh Editions. 2013; 138-141p.

18. RaneZab AK, Anusha B. Phytochemical evaluation by GC-MS and in vitro antioxidant activity of Punica granatum fruit rind extract. J Chem Pharm Res. 2012; 4(6): 2869-2873.

19. Garach D, Pake A, Chakraborty M, Kamath JV. Phytochemical and pharmacological profile of Punica granatum: an overview. Intr Res J Pharm. 2013; 3(2): 65-68.

20. Farag $R$, Abdelatif $M$, Emam S, Tawfeek $L$. Phytochemical screening and polyphenol constituents of pomegranate peels and leave juices. Agr Soil Sci.2014; 1(6): 86-93.

21. Heber D. Multitargeted therapy of cancer by ellagitannins. Cancer Lett.2008; 269: 262-268.

22. Babero GF, Liazid A, Palma M, Barroso CG. Ultrasound assisted extraction of capsaicinoids from peppers. Talanta. 2008; 75(5): 1332-1337.

23. Ma YQ, Chen JC, Liu $D H$, Ye XQ. Simultaneous extraction of phenolic compounds of Citrus pee extracts: effect of ultrasounds. Ultrasonsonochem. 2009; 16 (1): 57-62.

24. Kokate KC. Pratical pharmacognosy, 4th edition, Delhi: VallabhPrakashan. 1997; 128p.

25. Harborne JB. Phytochemical methods: a guide to modern techniques of plant analysis, 2nd edition, London: Chapmand and Hall. 1998; 54-84p.

26. Guide for care and use of laboratory animals. National Academy of Sciences Committee for the Update of the Guide for the Care and Use of Laboratory Animals, the National Academies Press, 8e edition. 2011

27. Shah Ayub MA, Garg SK, Garg KM. Subacute toxicity studies on Pendimethalin in rats. Indian $J$ Pharmacol.1997; 29: 322-324.

28. Bürger $C$, Fischer DR, Cordenunzzi DA, Batschauer de Borba AP, Filho VC, Soaresdos Santos AR. Acute and subacute toxicity of the hydroalcoholic extract from
Wedeliapaludosa (Acmelabrasilinsis) (Asteraceae) in mice. J Pharmacol Sci. 2005; 8(2): 370-373.

29. Thanabhorn S, Jaijoy $K$, Thamaree S, Ingkaninan $K$. Acute and subacute toxicities of the ethanol extract from the fruits of Terminaliabelerica (Gaertn) Roxb. J Pharm Sci. 2006; 33(1-4): 23-30.

30. Pello C. Acute oral toxicity in rats "acute toxic class method" test item. Rapport confidential, CIT, Evreux. 2005.

31. Uma Shankar S, Umesh Kumar S, Abhishek S, Niranjan S, Puspak JS. Screening of Terminaliabellirica fruits extracts for its analgesic and antipyretic activities. Jordan J Biol Sci. 2010; 3(3):121-124.

32. Koster $R$, Anderson M, Rehan HMS. Acetic acid analgesic screening. Federation proceeding. 1959; 18 : 418.

33. Taber RI, Greenhouse DD, Rendel JK, Irwin S. Agonist and antagonist interaction of opoids on acetic acid induced abdominal stretching in mice. $J$ Pharmacol.1969; 169: 29-37.

34. Singh S, Maumder DK, Rehan HMS. Evaluation of antiinflammatory potential of fixed oil of Ocimum sanctum (Holybasil) and its possible mechanism of action. $J$ Pharm Pharmacol.1996; 38: 627.

35. Wani TA, Kumar D, Prasad R, Kumar Verma $P$, Sardar KK. Tandan SK. Kumar, D. Analgesic activity of the ethanolic extract of Shorearobusta resin in experimental animals. Indian J Pharmacol. 2012; 44(4):493-499.

36. Collier HO, Dinneen LC, Johnson CA, Schneider C. The abdominal constriction response and its suppression by analgesic drugs in the mouse. BrJ PharmacolChemother. 1968; 32: 295-310.

37. Naveed M, Saeed M, NaeemuddinGilani S, UlHaq I, Khan $\mathrm{H}$. Analgesic and anti-inflammatory profile of $n$ Hexane fraction of Viola betonicifolia. Trop $\mathrm{J}$ Pharm Res. 2012; 11(6): 963-969.

38. Hoque N, RazibulHabibi Md, Zafar Imam M, Jamiuddin A, SohelRana Md. Analgesic and anti-inflammatory potential of methanolic extract of Glinusoppositifolius $L$. Aust J Basic \& app/ sci. 2011; 5(8): 729-733.

39. Paulino N, Dankas AP, Bankova V, Longhi DT, Scremin A de Castro SL, Calixto JB. Bulgarian propolis induces analgesic and anti-inflammatory effects in mice and inhibits airway smooth muscle. J. Pharmacol Sci.2003; 93: 307-313.

40. Bektas N, Arslan R. Antinociceptive effects of methanol extract of Capparisovate in mice. Pharm Biol. 2010; 48: 1185-1190.

41. Kennedy GL, Ferenz RL, Burgess BA. Estimation of acute oral toxicity in rats by determination of the approximate lethal dose rather than the LD50.J Appl\&Toxicol.1986; 6: 148-148.

42. Bentley GA, Newton SH, Starr J. Studies on the antinociceptive action of a-agonist drugs and their interactions with opioid mechanisms. $\mathrm{Br} J$ Pharmacol.1983; 79: 125-134.

43. Ribeiro RA, Vale MI, Thomazzi SM, Paschoalato $A B$, Poole S, Ferreira SH, Cunha FQ. Involvement of 
resident macrophages and mast cells in the writhing nociceptive response induced by zymosan and acetic acid in mice. Eur J Pharmacol. 2000; 387: 111-118.

44. Kartik JS, Sachdev D. Evaluation of antinociceptive and anti-inflammatory effect of the hydroalcoholic extracts of leaves and fruit peel of Punica granatum in experimental animals. Asian J Pharm \& Clin Res. 2010; 7 (2): 137141.

45. Miguel MG, Neves MA, Antunes D. Pomegranate (Punica granatum L); A medicinal plant with myriad biological properties. J Med Plants Res.2010; 4(25): 2836-2847.

46. Sadaiah B, Sunil Kumar KT, Kavitha CN, ManoharBabu $S$, Prabhakar Reddy V. Antinociceptive activity of methanolic extract of leaves of Vitis vinifera. Der Pharm Sinica. 2011; 2(2): 190-197.

47. GunoSindhu C. Analgesic activity of various extracts of Punica granatum (linn) flowers. Int J green pharm. 2008; 2(3): 145-146.

48. Priyanka B, Mohd A, Vidhu A, Shahnaz S, Malay B. Evaluation of anti-inflammatory and analgesic activity of Punica granatum L. Int J drug dev\& res. 2010; 2 (4).

49. Gupta JK, Sharma SK, Misra V, Patel K. Evaluation of anti-nociceptive and anti-inflammatory activity of Punica granatum seed extract. Int Res J Pharm. 2011; 2(12): 235-237.
50. Nain P, Aini M, Malik M. Evaluation of anti-inflammatory and analgesic activity of Punica granatum Linn leaves. Int J Res in Ayurveda \& Pharm. 2011; 2(3): 987-990.

51. Swarnamoni $D$, Renuka SS, Shagufa $A$, Lalit $K$. Analgesic and anti-inflammatory activities of ethanolic extract of leaves of Punica granatum $L$ on experimental animal models. Pharmacol.2011; 3: 379-385.

52. Olapour S, Najafzadeh $H$. Evaluation analgesic, antiinflammatory and antiepileptic effect of hydro alcoholic peel extract of Punica granatum (pomegranate). Asian $J$ MedSci. 2010; 2(6): 266-270.

53. Bensaad L, KahHwi K, Alsereti M, Shahimi M. Evaluation of the analgesic effects of Libyan fresh pomegranate fruit of Punica granatum. Pharma Nutr. 2013; 2: 75-119.

54. Saad LB, Hwi KK, Quah T. Evaluation of the antinociceptive effect of the ethanolic extract of Punica granatum. Afr J Trad Comp \& Alternative Med 2014; 11 (3):228-232.

55. Lamees ABS, Kah HK. Phytochemical constituents and analgesic activity of ethyl acetate fraction of Punica granatum L (Punicaceae).Trop J Pharm Res. 2015; 14(1): 87-93.

56. Jyoti S, Ajay KS, Anand S. Analgesic and antiinflammatory activity of methanolic extract of Vitis vinifera leaves. Pharmacol 2009; 3:496-504. 